\title{
Women Leadership Based on Local Wisdom
}

\author{
Yuni Lestari ${ }^{1, *}$ Agus Prastyawan ${ }^{1}$ Prasetyo Isbandono ${ }^{1}$ \\ ${ }^{I}$ Public Administration of Vocational Program,Universitas Negeri Surabaya, Indonesia \\ ${ }^{*}$ Corresponding author. Email: yunilestari@unesa.ac.id
}

\begin{abstract}
The struggle of women to occupy the position of women is not as easy as men. The totality of domestic and public roles that are carried out simultaneously by women leads to a dual role that must be played. The perpetuation of the wrong perception of the division of roles between men and women further exacerbates the situation. The patriarchal culture is also a measure of the inappropriateness of women to occupy leadership positions. This misunderstanding does not only come from men and society, even many women are not aware of the roles they carry out. In writing and analyzing this article, the author uses a literature review approach. The author tries to analyze the critique of the role of women leaders in utilizing local wisdom. The study of gender and women is still a study that is quite controversial in some circles. Likewise, the study of women leaders in villages has become a topic of pro and contra in many types of research. Village leaders as the front line of government in establishing direct relationships with the people, so the leaders should learn and master every culture as a source of local wisdom. Local culture, values, and norms become a social capital for women leaders in determining the good leadership style so the leadership success can be realized.
\end{abstract}

Keywords: local wisdom, indigenous leadership, women leader, leadership

\section{INTRODUCTION}

Indonesian culture is very paternalistic, encourages women to fight harder to occupy leadership positions. It is not wrong when a public statement appears that says to occupy the leadership position, women must try 2 or 3 times stronger than men [1]. People's perceptions like that are the beginning of gender inequality in the world of leadership, especially women. Women are constantly trying to balance the roles between work and family. The role of women as mothers and wives must be maintained properly, meanwhile, the role of women as professionals and career success is an unavoidable choice. Those Conditions are increasingly pushing women into the "double burden".

The phenomenon in Indonesia shows that many female leaders occupy parliamentary seats. However, of the many women, only a few are compete for executive positions. In the General Election of 2019 in Surabaya City, the fulfillment of the $30 \%$ quota for women's representation only reached the DCS (Daftar Calon Sementara/Temporary Candidate List) or DCT (Daftar Calon Tetap/Permanent Candidate List). The quota also fell below $30 \%$ when entering the selection stage or determining the Selected Candidate List. The process has been carried out properly and correctly, but the fulfillment of the quota for the representation of women in political parties in the nomination is only for legalization. There is no full awareness, let alone the credibility and competence of DCS or DCT. Political parties pick women to be representatives of political parties so that they meet the requirements and are registered as valid political parties participating in the election [2].

Direct and real interactions between leaders and followers can be seen in village leadership. The village head as the top leader at the village level has the responsibility to realize village establishment and independence. From the data from the Central Statistics Agency for East Java Province in 2018, it is known that of the 8,268 village heads in East Java, 812 of them are female village heads. The data represents the number of women who take part in the realm of leadership does not reach $10 \%$ of the total [3].

Local wisdom of indigenous is interpreted as a form of culture that is rooted in and believed by the local community. Sudikan revealed that culture is social capital in development in Indonesia [4]. Social capital is part of community capital. The idea that society can't solve social problems individually, encourages further thinking that social interaction is very important in culture [5]. Culture, values, and norms or social capital must be recognized and understood well by a leader.

The existence of local wisdom as social capital is a tool that helps a leader in carrying out the leadership process in particular. A leader who can adapt to the culture of the local community will undoubtedly have the convenience of building public trust as a follower. The study in Africa stated that leadership there was created by paying attention to indigenous values [5]. Furthermore, the theoretical framework in the analysis of this article can be seen in Figure 1. 


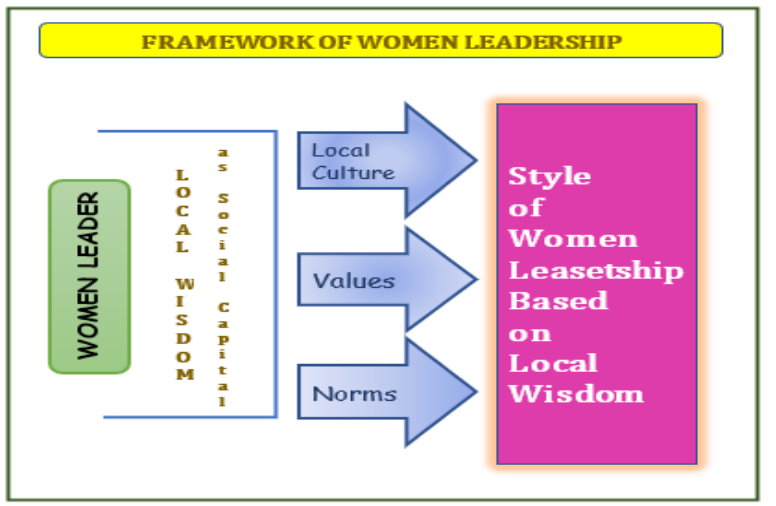

Figure 1. Theoretical Framework of Women Leadership Based on Local Wisdom

\section{METHOD}

A literature review is a method of critically analyzing, evaluating, and synthesizing research findings, theories and practices carried out by researchers and scholars. In this method, the author presents a comprehensive, critical, and accurate understanding of current knowledge [6]. In line with this opinion, Romi Satria Wahono, an expert in research methodology, explained that literature review does not only mean reading literature but rather towards an in-depth and critical evaluation of previous research on a research topic. The results of the evaluation are then summarized, analyzed, synthesized the content, and presented in the form of a survey paper [7].

\section{RESULT AND DISCUSSION}

\subsection{Gender-Based Leadership}

Organizational success is often associated with a leadership profile that has a large influence. The skills or strengths of a leader greatly affect the leadership style in achieving organizational success. Fitriani argues that the skills or strengths of the leader are the capital for the leader to be able to influence others to achieve certain goals through certain activities (such as caring for, supporting, and motivating subordinates) [8][9][10]. A good leader is expected to be able to bind, harmonize, and encourage subordinates to compete in a healthy manner.

Leadership expert in Indonesia, Kartono explains the definition of leadership from 6 perspectives [11]. First, leadership as focus groups. The existence and personality of the leader as a source of an image that unites the group. Second, leadership has a personality and effect. Leaders are examples of good character and personality, and greatly influence the character of followers. Third, leadership is the art of influencing others. The ability of a leader is seen from the ways to hire others for certain goals with the smallest possible friction, resulting in high obedience, respect, loyalty, and cooperation. Fourth, Leadership is the use of influence. The ability of a leader is seen from the expertise to influence others. Fifth, leadership as a power relationship. In this perspective, power relations have an important role for leaders in influencing others. Sixth, leadership as a difference of opinion. The concept of leadership is seen as a process of learning/training a person in influencing others, starting from the level of being influenced to the level of influencing. The above perspective uses a very complex point of view in looking at the concept of leadership.

In the appropriateness and appropriateness of leadership for both men and women, the competencies possessed by leaders are the most fearful indicators that can be used to assess a person's suitability to occupy a leadership seat. A leader should have 3 main characteristics [12], including (a) Social Perception, the leader's ability to see and understand the attitudes/behavior and needs of subordinates; (b) Skill of Abstract Thinking, the leader has high intelligence and the ability to think simply; (c) Emotional Balance, a leader has emotional maturity (deep awareness of needs, desires, ideas, and feelings), to create a harmonious personality. When women have the competencies and characteristics of leaders, it is inappropriate when there is still a perception that women are said to be unfit to occupy leadership seats.

Religious doctrine is often used as a measuring indicator of the appropriateness of women to occupy leadership positions. Klenke researches women's leadership in the context of religion and spirituality. The research stated that the history of religion and the church has provided opportunities for anyone to become a leader. This also applies to female religious leaders despite opposition from seniors. Existing developments have brought changes where the roles of women and men in the church have also changed. If there is a difference between the two, it is only limited to biological differences but not gender roles [13]. The thing to remember when women become leaders must be based on selfsupportive qualities [14].

In the same context, Islam has explained that men and women have the same position and the difference between the two is the level of piety to Allah SWT. Surah At-Taubah verse 71 can be translated as follows: "And those who believe, male and female, some of them (are) a helper for some others. The command (do) what is right, prevent what is evil, establish prayer, pay zakat, and obey Allah and His Messenger. They will be blessed by Allah. Verily Allah is Mighty and Wise." The verse very clearly explains the equal position between men and women and both were created to work together and complement each other [15]. This statement is sufficient reason to explain that both women and men have equal opportunities to occupy leadership positions.

A study published in one of the Jobsite emails in the UK (United Kingdom), as explained by Paula that a lot of data (especially the UK) shows that almost half of the workforce in the country are women, but it is unfortunate when women have not been able to occupy leadership positions. Not only the difference in career advancement especially in the British states but women are also discriminated against in pay. The basic salary of full-time female workers is $82 \%$ of the salary received by male workers, while the part-time salary of female workers is $60 \%$ of the salary earned by male workers [16]. If the data above still shows discrimination against women for public recognition, then the conditions in Lebanon are much different. Gender discrimination between men and women is now a story of the past that is starting to be abandoned. The results of a study by Hejase and colleagues on Women's Leadership in Lebanon, shows that women have received recognition (from seniors) at the level of workability. However, to occupy top managerial positions, female workers need certain strategies and stages. The existence of the Law on Gender Representation (Laws Concerning Gender 
Representation) is also very helpful for women to reach the top management level in an organization [16].

Several phenomena in Indonesia show many female leaders have occupied parliamentary seats at the central (national), provincial, and district/city levels. However, of the many women, only a few can compete for executive seats. The real challenge for women is how to create a representation of women in politics that is not only about gender issues or women's quotas. It is time for gender mainstreaming to become a worldview of state politics and governance [17]. The concept of competition created in the relationship between men and women must be ended immediately. Parawansa illustrates that the concept of partnership is the right concept to build a relationship between the two sexes [18]. The concept of partnership leads to the creation of collective power distribution.

The table below can strengthen the statement that in the end the involvement of women in parliament has not been able to fulfill the quota for representation from year to year. The representation of women at the center is still fluctuating, ranging from $17 \%$ to $18 \%$. The less encouraging thing happened in East Java, where the percentage of women's representation tends to decrease. The involvement of women had increased by $1 \%$ from 2011 to 2012 , but this did not last long [19].

Table 1. Involvement of Women in Parliament (\%)

\begin{tabular}{|c|c|c|}
\hline Years & Indonesia & East Java \\
\hline 2010 & 17.49 & 18 \\
\hline 2011 & 17.49 & 18 \\
\hline 2012 & 18.04 & 18 \\
\hline 2013 & 18.04 & 19 \\
\hline 2014 & 17.32 & 15 \\
\hline 2015 & 17.32 & 15 \\
\hline 2016 & 17.32 & 15 \\
\hline 2017 & 17.32 & 15 \\
\hline 2018 & 17.32 & 15 \\
\hline
\end{tabular}

Resource: Badan Pusat Statistik [19]

The representation of women in parliament has not yet been able to be used as a reference for success for women's leadership in Indonesia. We can see the low involvement of women at the top of executive leadership from the Indonesian Ministry of Home Affairs data on the names of Governors and Deputy Governors in 2018. The data states that as many as 34 Governors and 28 Deputy Governors from 34 provinces, there is only 1 female Governor, and 3 female Deputy Governors [20]. The representation of women leaders in East Java can be seen from the electability of women as regional heads (Bupati/Mayor) and deputy regional heads. Reporting from data from an online report, it is known that of the 38 Regents/Mayors in East Java who have served until 2020, there are 5 (five) regional heads who are carried by women [21]. From the data, it is also known that 20 positions of deputy regional heads were filled, of which 3 women filled these positions. Although it has not yet reached $20 \%$ of all inaugurated regional heads, the representation of women in the executive realm is one of the proud achievements of East
Java. Of the 14 women from all over Indonesia who were appointed as regional heads at both levels I and II, 6 of them came from East Java.

The next data relates to women's leadership at the local village level. Based on BPS data, the number of Villages by Gender of The Village Head (Lurah) and Village Secretary in 2018 in East Java was 8,268 people. The data is divided into 7,456 male Village Heads (Lurah) and 812 female Village Heads [3]. The number of female Village Heads represents the number of women who take part in the realm of leadership which does not reach $10 \%$ of the total number.

The next data relates to women's leadership at the local village level. Based on BPS data, it is known that the number of Villages by Gender of The Village Leaders and Village Secretary in 2018 in East Java were 8,268 people. The data is divided into 7,456 male Village Heads/Lurah and 812 female Village Heads/Lurah [3]. The number of female Village Leaders represents the number of women who take part in the realm of leadership which does not reach $10 \%$ of the total number.

\subsection{Leadership in Local Wisdom Concepts}

Local wisdom as a form of in-depth study of a culture can also be a tool for leaders to perpetuate power. Taylor explains that culture as a complex thing includes knowledge, belief, art, morals, law, customs, and other abilities, as well as habits acquired by humans as members of society [22]. In leadership in the village, the leader is expected to be able to utilize and collaborate with the local culture. The cleverness of the leader in managing non-formal relationships is also expected. The thick family relationship is one of the characteristics of rural communities that can be studied well by a leader so that it can be used as positive capital for leaders in formulating successful leadership strategies.

Local wisdom can be interpreted as a form of culture that is rooted in and believed by the local community. In a book entitled "Local Cultural Wisdom", Sudikan reveals that culture is social capital in development in Indonesia [4]. Hasbullah identified social capital in 6 (six) elements, namely (1) related family and relatives, (2) association life which involves formal relationships in a horizontal affair, (3) network, (4) political society that becomes the mediator between public and state relations, (5) institutions and policy frameworks that involve formal rules and norms governing public life, and (6) social norms and social values [4]. Thus the idea arises that society can't solve social problems individually. Social interaction has an important role in the formation of a culture.

Local culture has an important role for leaders in determining their leadership style. In the typology of social sociology, East Java is divided into 4 (four) East Javanese cultural groups, namely: Mataraman, Arek (Suroboyoan), Pandalungan, and Madura. Researchers believe that these cultural groupings certainly influence the characteristics of the community so that the cultural peculiarities of the community are formed. These cultural peculiarities certainly have an impact on the differences in the art of leading a leader in each region.

A study of women's leadership in Madura illustrates that social, cultural, and political support is very important for women leaders to be able to occupy leadership positions. Social support was obtained by a village head named 
"Srikandi" thanks to the good name of his late husband who previously served as village head. However, this is certainly not enough. Srikandi's morals, ethics, and experience while serving as chairman of the PKK as well as the wife of the previous village head are also strong considerations for the community to choose. During the thick patriarchal culture of the Madurese community, Srikandi convinces the community through achievements and abilities. Thus Madurese women can become leaders. Srikandi also uses experience in government organizations to gain political support. The achievements have become the basis of Srikandi's appropriateness to walk forward to the leader's chair [23]. Srikandi is a depiction of the extraordinary efforts made by women to be able to occupy leadership seats during a very contradictory culture.

The importance of culture in leadership is also written by Onukwuba in his research entitled "Indigenous Management Practices in Africa". In this study involving 200 respondents, it was explained that as many as $90 \%$ of respondents believed that culture played an important role in the formation of leadership styles in Africa. As a former European colony, they realize that this has an influence on indigenous leadership, the spirit of the leader, or his followers [5].

In a previous study conducted by the author on the Study of Women's Style and Leadership in Bangkalan Madura Regency, Madurese female leaders encountered obstacles both in the process of obtaining leadership positions and in the process of carrying out the leadership. It is undeniable that the choice of female "klebun" (Women's Village Head) cannot be separated from the presence of men behind them. The strong male profile behind the election of female leaders is one of the capitals for women in occupying leadership. The success of Madurese women in occupying leadership positions cannot change the perception of the Madurese community that men still have a special leadership role. The seriousness or lack of seriousness of women in carrying out their positions is a separate profile for Madurese women leaders. In the process of carrying out their leadership duties, the two female leaders who were the main informants in this study concluded that they both have different leadership styles. The first female leader has a strong commitment to her leadership. This can be seen from how the leader's concern for the community (duties as public servants) and his dexterity in carrying out administrative tasks (duties as bureaucrats. The second female leader tends to delegate most of her duties to the Village Office staff. The high trust of female leaders This to staff becomes a separate obstacle to a leader's commitment [24]. Regardless of how the strategy of women leaders to achieve leadership positions, it becomes an important component that women leaders must have the ability and commitment in carrying out leadership. During a strongly patriarchal culture, every activity carried out by women leaders was a measure of success and even a separate profile for women leaders.

\section{CONCLUSION}

The progress of the times and modernization can not erase the strong patriarchal culture of several regions in Indonesia. The existence of this culture is a challenge for women's leadership. In the patriarchal culture, there are still wide opportunities for women to occupy leadership positions. The female leaders even have to fight stronger than men. Anyone has the opportunity to be a leader, male or female. Successful leaders are not seen from gender, but how leaders have certain competencies to be able to carry out the duties and functions of leaders.

Every diversity of an area becomes social capital for leaders to carry out their leadership. Local wisdom of indigenous is a strength for every leader to see and read the culture and desires of the community. The leader's commitment and concern for the community be seen from their ability to adapt to the community.

\section{ACKNOWLEDGMENT}

A big thank to the Rector of Universitas Negeri Surabaya. Thanks for giving support and international conference funding. By those, this international proceeding paper can be carried out.

\section{REFERENCES}

[1] P. Anggahegari and D. C. Lantu, "The Acceptance Of Women Leadership In Indonesia In Correlation With Organizational Performance," vol. 1, pp. 232-237, 2014.

[2] Y. Lestari, A. Prastyawan, and P. Isbandono, "Formulasi strategi partisipasi partai politik dalam meningkatkan kuota keterwakilan perempuan pada pemilu 2019," vol. 1, no. 1, pp. 52-61, 2019.

[3] BPS Provinsi Jawa Timur, "Banyaknya Desa/Kelurahan Menurut Jenis Kelamin Kepala Desa/Lurah dan Sekretaris Desa/Kelurahan, 2018," Surabaya, 2019

[4] S. Y. Sudikan, Kearifan Budaya Lokal, 1st ed. Sidoarjo: Damar Ilmu, 2013.

[5] H. O. Onukwuba, "Indigenous leadership practices in Africa," Adv. Ser. Manag., vol. 20, pp. 119-145, 2018.

[6] S. E. Efron and R. Ravid, Writing The Literature Review: A Practical Guide. London, New York: The Guilford Press, 2019.

[7] R. S. Wahono, "LITERATURE REVIEW: PENGANTAR DAN METODE," RomiSatriaWahono.Net, 2016. [Online]. Available: https://romisatriawahono.net/2016/05/07/literaturereview-pengantar-dan-metode/. [Accessed: 25-Jul2021].

[8] A. Fitriani, "Gaya Kepemimpinan Perempuan," $J$. TAPIs, vol. 11, no. 2, pp. 1-24, 2015.

[9] M. N. Wexler and J. Oberlander, "Public leadership and the wicked problem continuum," Int. J. Public Leadersh., vol. 16, no. 4, pp. 359-373, 2020.

[10] K. Jermsittiparsert, "Factors of Successful Women Leadership in Asian: Moderating Role of Political Differences and Organization Culture," Agil. Bus. Leadersh. Methods Ind. 4.0, pp. 259-284, 2020.

[11] K. Kartono, Pemimpin Dan Kepemimpinan. Jakarta: PT. Bumi Aksara, 2016. 
[12] S. P. Robbin, Perilaku Organisasi: Konsep, Kontroversi, Aplikasi. Jakarta: Prenhallind, 1996.

[13] B. D. Djasmoredjo, "Persepsi Karyawan Laki-laki Terhadap Pemimpin Perempuan: Apakah Pemimpin Perempuan Lebih Bersifat Asuh Daripada Pemimpin Laki-laki?," J. Widya Manaj. Akunt., vol. 4, no. 3, 2004

[14] K. Klenke, Women in Leadership 2nd Edition. 2017.

[15] M. Q. Shihab, Quraish Shihab Menjawab 1001 Soal Keislaman Yang Patut Anda Ketahui. Jakarta: Lentera Hati, 2011.

[16] H. Hejase, Z. Haddad, B. Hamdar, R. Massoud, and G. Farha, "Female Leadership: An Exploratory Research from Lebanon," Am. J. Sci. Res., no. 86, pp. 28-52, 2013.

[17] D. Candraningrum, "Raison d'etre Pengarusutamaan Gender dalam Kabinet Kerja 2014-2019: Perempuan, Nalar Keadilan \& Tata Kelola Pemerintahan," J. Peremp., vol. 19, no. 4, pp. 123-140, 2014.

[18] S. Andajani, O. Hadiwirawan, and Y. A. Sokang, "Current Discussion , Barriers , and Existing
Stigma," vol. 4, no. 1, pp. 101-111, 2016.

[19] Badan Pusat Statistik, "Keterlibatan Perempuan di Parlemen Menurut Provinsi, 2010-2018," Jakarta, 2020 .

[20] Kemendagri RI, "Gubernur dan Wakil Gubernur," Kementerian Dalam Negeri RI, 2018. [Online]. Available:

https://www.kemendagri.go.id/page/read/14/gubern ur-dan-wakil-gubernur. [Accessed: 23-Jan-2021].

[21] L. A. Azanella, "14 Perempuan yang Terpilih sebagai Kepala Daerah pada Pilkada Serentak 2018," Kompas, Jakarta, 30-Jul-2018.

[22] S. Soekanto and B. Sulistyowati, Sosiologi Suatu Pengantar, Revisi. Jakarta: PT. Rajagrafindo Persada, 2014

[23] A. J. Karim, "Kepemimpinan Perempuan Madura," Mimbar, vol. XXIII, no. 2, pp. 221-234, 2007.

[24] A. Prastyawan, Y. Lestari, and F. Pribadi, "Kajian Gaya dan Fungsi Kepemimpinan Perempuan di Kabupaten Bangkalan Madura,” Surabaya, 2019. 